\title{
Developmentalism as a comparative-historical model: From Friedrich List to Bresser-Pereira
}

\author{
O desenvolvimentismo como modelo histórico-comparativo: \\ de Friedrich List a Bresser-Pereira
}

WALID TIJERINA*

\begin{abstract}
RESUMO: A literatura sobre o Novo Desenvolvimentismo reformulou as características do estado desenvolvimentista ao longo das diferentes conjunturas históricas experimentadas na ordem internacional. Este artigo argumenta que o desenvolvimentismo se reinventa como um ramo do método histórico-comparativo. Para conseguir isso, o artigo avalia a evolução do desenvolvimentismo como um método histórico-comparativo que foi consolidado como uma continuação de modelos de desenvolvimento anteriores, como o sistema nacional de List e o estruturalismo de Prebisch. Da mesma forma, este artigo explorará o Novo Desenvolvimentismo e seu poder explicativo sobre as recentes estratégias industriais na América Latina.
\end{abstract}

PALAVRAS-CHAVE: Estado de desenvolvimento; América Latina; políticas comparativas; economia política.

ABSTRACT: The literature on New Developmentalism has been reframing the developmental state's characteristics throughout the different historical conjunctures experienced within the international order. This paper argues that developmentalism has been reinventing itself as a branch of the comparative-historical method. To achieve this, the article assesses the evolution of developmentalism as a comparative-historical method which has been consolidated as a continuation of previous development models, such as List's national system and Prebisch's structuralism. Likewise, this paper will explore New Developmentalism and its explanatory power regarding recent industrial strategies in Latin America.

KEYWORDS: Developmental state; Latin America; comparative politics; political economy. JEL Classification: P5.

\footnotetext{
* Universidad Autónoma de Nuevo León, Facultad de Ciencias Políticas y Relaciones Internacionales, Monterrey/Nuevo León, México. E-mail: walid.tijerinaspv@uanl.edu.mx. ORCID: 0000-0002-08567103. Submitted: 17/December/2019; Approved: 21/January/2020.
} 


\section{INTRODUCTION}

During the end of the $20^{\text {th }}$ century, a majority of Latin American countries which had been experimenting with import-substitution industrialization (ISI) began undertaking a transition to a neoliberal oriented model. This shift in their political economy was influenced in large part by the World Bank's and International Monetary Fund's roles as implementers of the Washington Consensus (Bresser-Pereira, 1993). The promulgated benefits of the Washington Consensus, however, began to be contested after several crises across the globe during the 1990s, such as the Tequila crisis (1994) that spread from Mexico across Latin America and the economic crisis in East Asia (1997). A decade later, the role of neoliberalism as the political economic paradigm across the globe would be even more contested after the financial crisis of 2008 . From that moment on, the previously latent uncertainties were extended as to whether neoliberal economic policies or the so-called Washington Consensus continued to be the best route to follow for the development and/or economic recovery of countries. This overthrow of neoliberalism as a hegemonic paradigm in economic policy for both developed and developing countries has thus been increasingly associated with a global wave of disenchantment in relation to the policies of laissez-faire, austerity, and economic integration in European and American countries.

Consequently, developing and developed countries alike have begun to press again to return to practices and strategies which were rather common prior to the Washington Consensus and the World Trade Organization (WTO), where each country had the freedom (or sovereignty) to design the industrial policies that could better adapt to their socioeconomic circumstances - including measures such as import tariffs, subsidies and exchange controls, among others. It is within this context, therefore, that New Developmentalism has gained increasing attention, both by academics and policy practitioners.

Thus, the aim of this paper is to explore the evolution of developmentalism as a policy regime and Classical as well as New Developmentalism as a theoretical framework adopting a comparative-historical method, along with its recent implications amid a recent expansion of policy space across the globe. The latter will hopefully highlight how the recent reconfiguration of the international political economy has put to the test previous orthodoxies for promoting economic development at a national scale. To pursue such aim, therefore, this paper will briefly analyze the theoretical origins and evolution of Developmentalism, with the objective of extrapolating the implications that this political economic model may have on evolving industrial strategies of middle-income countries. ${ }^{1}$

In the first section of this paper, the origins of Developmentalism will be traced to economists whose contributions revolved mostly around European states, with a

\footnotetext{
${ }^{1}$ Note that I will use Classical and New Developmentalism with capital letters when I am referring to the theoretical framework, while developmentalism with lower case to the policy regime or the form or capitalism alternative to economic liberalism.
} 
particular emphasis on Friedrich List. In the second section, Prebisch's Classical Developmentalism and its contributions to analytical frameworks for Latin America's economic development will be reviewed, emphasizing it as a "systemic, multidimensional and historically dynamic view of human societies" (Di Filippo, 2009: 175) well in tune with comparative historical approaches undertaken by List, Gerschenkron, and Bresser-Pereira. From here on, the paper will explore the latter's conceptualization of Developmentalism, from its "old" or "classical" conceptions to its "new" conception, stressing how the same comparative historical traits of this evolving theoretical model has enabled its adaptation to the variegated junctures of Latin America's development.

\section{STEPS OF STATE-LED INDUSTRIALISATION: LIST AND HIS SYSTEMS OF POLITICAL ECONOMY}

The comparative-historical method has thus far been a guiding tool for the reconfiguration of developmental literature. And in this particular aspect, Friedrich List's contribution to the developmental literature could well be considered as founding a tradition. According to Chang (2002: 6), the pioneering comparative method of List consisted of "searching for persistent historical patterns, constructing theories to explain them, and applying these theories to contemporary problems, while taking into account changes in technological, institutional and political circumstances".

Much as Tocqueville, in relation to Democracy in America, List profited from his experiences living in the United States (from 1825 to 1832) to give a clear and more integral version of the protectionism that was fostering the United States' industrial prowess vis-à-vis the free-trade or classic liberal model championed by England. These insights helped him write his treatise The Natural System of Political Economy, along with The National System of Political Economy. In these writings, List argued that England had become the industrial power that it was because, rather than in spite, of its early protection policies. List's whole premise of economic development, therefore, contradicted the classical liberal postulates of Adam Smith and Jean-Baptiste Say - which were correspondingly characterized by List as "one of the greatest falsehoods promulgated in the present century" ([1841] 2001: 25).

In List's consideration then, the state must be in charge of constructing those comparative advantages necessary to benefit from the international division of labor. In this order of ideas, "every nation that aspired to economic development had to increase its productive powers and, according to List's 'infant industry argument', reform its commercial policies according to its specific degree of development" (Pradella, 2014: 185).

With this refreshed equation of political economy, List took a comparative-historical approach to analyze the linked development of agriculture, manufacturing, and commerce in countries such as England, France, Spain, Portugal, United States, among others. In the process, he managed to elucidate how, in each case, commercial and industrial policies created particular paths towards growth, with the state's role 
at the center. At the same time, he managed to give political economy (as a national unit of analysis) its own place. List was thus particularly insightful when relating the protectionist strategies that brought forth the first industrial revolutions in countries such as England, Belgium, and France - which represent, in words of Bresser-Pereira (2016: 332), "the first historical form of developmentalism".

Many of the insights generated by List were later rescued by the developmental literature regarding the necessity of states to construct comparative advantages, rather than be dependent on static or natural comparative advantages as prescribed by classical economics. The German economist's comparative-historical works eventually served as the springboard for future thinkers such as Paul Rosenstein-Rodan (1961) and his "big-push" strategies, Albert O. Hirschman's (1958) and his "unbalanced strategy of economic development", and Alexander Gerschenkron (1962) with his conception of "economic backwardness". The contributions of these set of authors were particularly fitting to List's objective of bringing the state back into the political economy. Gerschenkron, in particular, honed the comparative-historical model of development in an effort to grasp the diverse industrializing patterns of modern states. He published his seminal work in 1962, a compilation of essays titled Economic Backwardness in Historical Perspective, which also contradicted the prevalent paradigm of laissez-faire or economic liberalism. In this regard, he stated that "a stronger medicine is needed than the promise of better allocation of resources or even the lower price of bread" in order to overcome a country's economic and industrial stagnation (Gerschenkron, 1962: 24).

One of the key concepts in Gerschenkron's work was what he termed "economic backwardness": a relative and, thus, comparative term for underdeveloped countries in relation to other more advanced countries. According to the RussianAmerican thinker, the degree of economic backwardness that a country presents determines the degree of intervention in state-led policies, the interaction between fostered industries (competitive versus monopolized), and the sources of investment for the country's development. It was through this seminal work that Gerschenkron advanced the comparative approach of industrialization first set out by List. Through these essays on European industrialization, with England seen as the role model for subsequent industrialized countries, he emphasized the necessity of avoiding overly generalized patterns of development in favor of patterns in which the particular deviations of each country ended up playing a fundamental part. Or as Gerschenkron (1962: 44) put it: "So viewed, the industrial history of Europe appears not as a series of mere repetitions of the 'first' industrialization but as an orderly system of graduated deviations from that industrialization".

From here on out, the Russian economist pinpointed the state's role in economic development at the gravitational centre of all of his case studies. In a similar manner to List, Gerschenkron also contradicted the recurring tendencies of laissezfaire or economic liberalism. In parallel to Gerschenkron's reformulation of the state's role in triggering economic development, Latin America began to consolidate its own school of thought regarding the region's "economic backwardness" and its necessity to industrialize in order to ameliorate its terms of trade and living standards. 


\section{FORGING A NEW DEVELOPMENT PARADIGM FOR LATIN AMERICA: FROM PREBISCH'S STRUCTURALISM TO BRESSER-PEREIRA'S DESENVOLVIMENTISMO}

In the same year in which Gerschenkron's seminal essays were published, the Economic Commission for Latin America (1962) reproduced another seminal essay through its Economic Bulletin "in view of the great demand for it in university circles and among economists” (p. 1). The essay was Raul Prebisch's “The Economic Development of Latin America and its Principal Problems" which was first published in Spanish in 1950 and had already garnered considerable attention from both academics and practitioners in the field of economic development. By the 1960s, just as the Latin American region was amid its second stage of ISI, this essay had already become a foundational reference for a talented group of economists working on Latin America, such as Aníbal Pinto, Oswaldo Sunkel, Juan Noyola, and Celso Furtado. Eventually, the collective work of these economists throughout the following years, led by Raúl Prebisch, outlined a school of economic thought which began to be known as "structuralism".

The central tenets outlined by Prebisch's (1962) Classical Developmentalism revolved around Latin America's impending necessity to industrialize due to the declining terms of trade for exports of primary products (see also Bresser-Pereira, 2000) - terms which were accordingly underscored by the Prebisch-Singer hypothesis. Similar to List's and Gerschenkron's arguments against classical liberalism's theories of international division of labour and static comparative advantages, Prebisch posited that the structural characteristics of international trade between an industrialized centre (led by the United States) and an underdeveloped periphery (which included the Latin American region) were increasingly beneficial for the former in detriment to the periphery. In Prebisch's (1962: 1) own words in regard to Latin America, "reality (was) undermining the out-dated schema of the international division of labour".

Consequently, the solution in Prebisch's perspective was to actively encourage a structural change in Latin America through industrialization. Following Keynesian premises, Prebisch thus called for anti-cyclical policies consisting of industrial subsidies, wage increments, an expansion of public investment, protection of infant industries, affordable credit, and foreign exchange controls in order to trigger the industrial transformation of Latin American countries. One of his policies that went by rather overlooked by Latin American countries during their ISI process, however, was the promotion of manufacturing exports. In Prebisch's (1962: 3) perspective, “exports not only provide the foreign exchange with which to buy the imports necessary for economic development, but their value usually includes a high proportion of land rent" without any associated collective costs.

A decade later after Gerschenkron's essays on economic backwardness and ECLAC's translation of Prebisch's essay, scholar testimonies of echoing industrial strategies surfaced in regard to Brazil's milagre econômico and East Asia's miracle. In the first developmental appraisal in the American continent, Bresser-Pereira's (1973) developmental [desenvolvimentista] account of the Brazilian economic mira- 
cle highlighted the role of the State in triggering the country's rapid industrial transformation. In order for Brazil to overcome its economic-backwardness, it implemented an ISI model consisting of vertical industrial policies, protection of infant industries, creation of state-owned enterprises, and a high ratio of public investment in infrastructure (see Bresser-Pereira, 1973, 2000). An account that was paralleled through Chalmers Johnson's analysis (1982) of the Japanese Miracle and the Ministry of International Trade and Industry's (MITI) role in the country's industrialisation.

Overall, from the 1930s to the 1980s, Latin America grew at extraordinary rates through what was accurately defined as "national developmentalism": consisting of "national development strategies that, in essence, implied protection of the infant national industry (or import-substitution industrialization) and the promotion of forced savings by the state" (Bresser-Pereira, 2009: 110). This model was best exemplified in the region through the regimes of Getulio Vargas in Brazil and Lázaro Cárdenas' redrawing of Mexico's development. Classical Developmentalism had thus been constituted by a "historical-deductive method" (Bresser-Pereira, 2018) which criticized prevailing conceptions of static comparative advantages, whilst promoting state activism, protection of domestic industries, and the consolidation of a "developmental class coalition" which united industrialists, workers, and bureaucrats (see Bresser-Pereira, 2016: 336).

Since the 1960s, nevertheless, the disregard of countries in the region for promoting exports, along with their profligate foreign debt, began to threaten the sustainability of this national developmentalist model until its eventual region-wide shutdown at the end of the 1970s and start of the 1980s. A shift to neoliberalism was then taken in the region. Some prophesized the end of developmentalism as both a theoretical and policy model, but the responses from both governments and researchers would soon show otherwise (see also Haggard, 2015).

\section{NEW DEVELOPMENTALISM AMID THE POST-HEGEMONY OF NEOLIBERALISM}

The market-oriented policies implemented by Latin American States since the 1980s did not provide the expected results. Eventually the extended economic stagnation and increasing rates of inequality in the region gave way to resurgence of leftist political parties in Latin America and to a revival of industrial policies. Particularly in Brazil, Lula da Silva's second term was characterized by its implementation of vertical industrialization programs, national development plans, and even a contestation to the World Trade Organization's constraints (Trubek, 2013). Thus, testimonies from left governments in Brazil and Argentina, along with the successful testimonies of East Asian Tigers as comparative benchmarks, posited academics and practitioners with a new puzzle: how to define a return to national developmentalist strategies amid testimonies from middle-income countries which now stressed innovation, competitiveness, integration to global productive chains, and public-private collaboration?

Within this context, Bresser-Pereira has built a new development macroeconom- 
ics and a new political economy of New Developmentalism in order to translate recent developmental strategies surfacing in middle-income countries. The new economic theory and political economy was labelled "New Developmentalism" by Bresser-Pereira (2003) and was promptly echoed by economists and scholars across the globe (see Ban, 2012; Schneider, 2015; Trubek, 2013; Tyerina, 2019). In a redrawing of classical developmentalism according to new historical conjunctures and in consideration of the successful industrialisations of Asian countries, the New Developmentalism strays away from traditional interventionist policies, heightening instead public-private collaboration as a cornerstone for eliciting productive investments, technological innovation, and export oriented growth, along with an emphasis on structuralist macroeconomics which underscore the importance of having a competitive exchange rate.

New Developmentalism thus gained momentum as a "new form of state activism" whose "economic nationalism means the adoption of a development strategy that allows domestic firms to seize global economies of scale and technological updating processes", whilst also promoting full employment, innovation, international trade, financial stability, and investment opportunities for national firms (Ban, 2012: 3). Therefore, it can very well be stated that the overall emphasis of recent developmental strategies has changed considerably according to comparative and historical conjunctures. Whereas old developmentalism stressed the importance of import substitution and protectionism through state intervention, New Developmentalism stresses instead innovation, human capital improvement, competitiveness, internationalization, and integration to global productive chains through public-private collaboration (Bresser-Pereira, 2016; Dvoskin and Feldman, 2018). It also stresses macroeconomic factors that somehow got lost along the way during Latin America's ISI period - which eventually contributed to its shutdown. For instance, the avoidance of indebtedness in foreign money not only as a preventive mechanism against balance-of-payment crises, but also as a way of avoiding the long-term overvaluation of the national money that makes the capable manufacturing companies non-competitive; the importance of getting five key macroeconomic prices or rates "right" (profit rate, interest rate, exchange rate, wage rate, and inflation rate); the promotion of technical progress in industry as a means to increase wages, standards of living, and productive sophistication; and the integration of post-materialist values of economic development, such as the consolidation of security, liberties, environmental protection, and reduction of inequalities (see Bresser-Pereira, 2016).

Along these lines of thought, New Developmentalism has become a "third way" between Classical Developmentalism (or Development Economics;) and the neoliberal orthodoxy, in the sense that it distances itself from the traditional interventionism (i.e., reliance on state-owned enterprises) of Classical Developmentalism, but still "considers the state an essential element in the development process, unlike the neoliberal orthodoxy, which sees the market as responsible for development" (BresserPereira ad Bechelaine, 2019: 760-1).

As of now, New Developmentalism, seems evermore like a necessary analytical framework considering the demise of market fundamentalism in both developed and 
developing countries. This disenchantment with the market-oriented policies of austerity and free trade have also contributed in bringing to the rise governmental programmes which once again emphasize the necessity of having a competitive domestic industry amid the continuing reconfigurations of the geopolitical economy. The aforementioned statements can be readily witnessed in the recent changes of the United States' paradigmatic role within the international economic order, contradicting its traditional role as free-trade champion. In parallel, countries in Latin America such as Mexico and Argentina have recently elected national governments whose main economic emphasis has been promoting domestic industries whilst reducing the rampant inequality across their population. International media, furthermore, have already considered the relation of the two countries as an embryonic "progressive alliance" in Latin America (EFE, 2019), setting the stage for wider policy-spaces regarding economic development.

\section{CONCLUSION}

After almost four decades of neoliberal hegemony across the globe, states have witnessed a galvanised response from political economies of developed, developing, and underdeveloped countries alike. In Latin America's middle-income countries, there is growing evidence of industrial and macroeconomic strategies which have been emphatic on regaining an industrial comparative advantage through publicprivate collaboration, wage increases, productive investments, and an interesting array of incentives targeted toward industrial upgrading and innovation.

Bresser-Pereira's continuing conceptualization of developmentalism, from old or classical to new, has thus posited an emphasis on the responsiveness of political economic paradigms to historical and structural circumstances. In words of BresserPereira (2019: 188), whereas "classical developmentalism reflected the conditions and challenges confronted by underdeveloped countries after the Second World War [...], New Developmentalism is a theory based on successful experiences of growth of middle-income countries", with a specific reference to Brazil in Latin America and East Asian countries such as South Korea and Singapore.

The previous statements underscore the relevance of the comparative-historical method in the continuing reconfiguration of developmentalism as a theoretical and policy model. In this order of ideas, New Developmentalism seems particularly suited to answer the call of middle-income countries in Latin America that are trying to trigger their industrial capabilities, raise their wages, and escape the persistent middleincome trap. The New Developmentalism therefore continues to be an essential analytical framework for Latin America's pursuit of overcoming detrimental terms of trade within the current configuration of international trade. 


\section{REFERENCES}

Ban, Cornel (2013) "Brazil's liberal neo-developmentalism: New paradigm or edited orthodo$\mathrm{xy}$ ?” Review of International Political Economy, 20(2), 298-331.

Bresser-Pereira, Luiz Carlos (1973) "O novo modelo brasileiro de desenvolvimento", Revista Dados, 11: 122-145.

Bresser-Pereira, Luiz Carlos (1993) "Economic reforms and economic growth: efficiency and politics in Latin America", in Bresser-Pereira, Maravall e Przeworski (1993) Economic Reforms in New Democracies (Cambridge: Cambridge University Press): 15-76.

Bresser-Pereira, Luiz Carlos (2003) Desenvolvimento e Crise no Brasil: História, Economia e Política de Getulio Vargas a Lula. Sao Paulo: Editora 34.

Bresser-Pereira, Luiz Carlos (2009) "From old to New Developmentalism in Latin America”, in Ocampo, José Antonio and Jaime Ros (eds.) Handbook of Latin America Economics. Oxford: University of Oxford Press.

Bresser-Pereira, Luiz Carlos (2016) "Reflecting on new and classical developmentalism", Review of Keynesian Economics, 4(3): 331-352.

Bresser-Pereira, Luiz Carlos (2017) "Historical models and economic syllogisms", Journal of Economic Methodology, 25, 2018: 68-82.

Bresser-Pereira, Luiz Carlos (2019) "From Classical Developmentalism and post-Keynesian macroeconomics to New Developmentalism”, Brazilian Journal of Political Economy, 155(2): 187-210.

Bresser-Pereira, Luiz Carlos and Cinthia Bechelaine (2019) "Multilateral development banks, New Developmentalism and local currency financing”, Brazilian Journal of Political Economy, 39(4): 755-767.

Chang, Ha Joon (2002) Kicking Away the Ladder: Developmental strategy in historical perspective. London: Anthem Press.

Di Filippo, Armando (2009) "Latin American structuralism and economic theory", Cepal Review.

Dvoskin, Ariel, and Germán David Feldman (2018) "A formal assessment of new-developmentalist theory and policy", Brazilian Journal of Political Economy 38(3): 395-413.

EFE (3 november 2019) “México y Argentina, ¿un nuevo eje progresista en América Latina?” Agencia EFE.

Gerschenkron, Alexander (1962) Economic backwardness in historical perspective, Cambridge: Belknap Press of Harvardy University Press.

Haggard, Stephan (2015) “The developmental state is dead: long live the developmental state.” In Advances in comparative-historical analysis, Cambridge: Cambridge University Press: 39-66.

Johnson, Chalmers (1982) MITI and the Japanese Miracle, Stanford: Stanford University Press.

List, Friedrich ([1841] 2001) The National System of Political Economy, London: Batoche.

Prebisch, Raúl (1962) “The economic development of Latin America and its principal problems”, Economic Bulletin for Latin America.

Schneider, Ben Ross (1999) "The Desarrollista state in Brazil and Mexico", in Woo-Cummings, M. (Ed.) The developmental state, Ithaca: Cornell University Press: 276-305.

Schneider, Ben Ross (2015) Designing industrial policy in Latin America: Business-state relations and the New Developmentalism, New York: Springer.

Tijerina, W. (2019) Industrial Development in Mexico: Policy transformation from Below. Abingdon: Routledge.

Trubek, David (2013) "Law, State, and the New Developmentalism. An Introduction", in Trubek, David et al. (Eds.). Law and the New Developmental State: The Brazilian Experience in Latin American Context, Cambridge: Cambridge University Press, pp. 1-27. 